MATEC Web of Conferences 38, 02004 (2016)

DOI: $10.1051 /$ matecconf/20163802004

(C) Owned by the authors, published by EDP Sciences, 2016

\title{
Analysis on the Performance of Copper Indium Gallium Selenide (CIGS) Based Photovoltaic Thermal
}

\author{
Afzam Zulkepli ${ }^{1}$, Lim Wei Yong ${ }^{1}$, Mohd Yusof Taib ${ }^{1}$, Zafri Azran², and Firdaus Basrawi1,a \\ ${ }^{1}$ ESFG, Faculty of Mechanical Engineering, UMP, Pekan, Pahang, Malaysia \\ ${ }^{2}$ Kuliyyah of Allied Health Sciences, IIUM, Kuantan, Pahang, Malaysia
}

\begin{abstract}
This paper deals with the efficiency improvement of Copper Indium Gallium Selenide (CIGS) Photovoltaic (PV) and also solar thermal collector. Photovoltaic thermal (PV/T) can improve overall efficiency for PV and also solve the problem of limited roof space at urban area. Objective of this study is to clarify the effect of mass flow rate on the efficiency of the PV/T system. A CIGS solar cell is used with rated output power $65 \mathrm{~W}$ and $1.18 \mathrm{~m}^{2}$ of area. 4 set of experiments were carried out, which were: thermal collector with $0.12 \mathrm{~kg} / \mathrm{s}$ flow rate, PV/T with $0.12 \mathrm{~kg} / \mathrm{s}$ flow rate, PV/T with $0.09 \mathrm{~kg} / \mathrm{s}$ flow rate and PV. It was found that $\mathrm{PV} / \mathrm{T}$ with $0.12 \mathrm{~kg} / \mathrm{s}$ flow rate had the highest electrical efficiency, $2.92 \%$. PV/T with $0.09 \mathrm{~kg} / \mathrm{s}$ flow rate had the lowest electrical efficiency, $2.68 \%$. It also had $2 \%$ higher overall efficiency. The efficiency gained is low due to several factors. The rated output power of the PV is low for the area of $1.18 \mathrm{~m}^{2}$. The packing factor of the PV also need to be considered as it may not be operated at the optimal packing factor. Furthermore, aluminium sheet of the PV may affect the PV temperature due to high thermal conductivity. Further study on more values of mass flow rate and also other parameters that affect the efficiency of the PV/T is necessary.
\end{abstract}

\section{Introduction}

Concerns on depletion of current reserved oil and worsening environmental problem have encouraged research towards green power generation. Photovaltaic (PV) emerged as one of the promising system with clean, low maintenance cost, and environmental friendly characteristics [1].

A Photovoltaic thermal $(\mathrm{PV} / \mathrm{T})$ collector is a module that combining PV with solar thermal collector [2]. PV generates electricity from solar radiation through photoelectric effect, while solar thermal collector will absorb solar radiation and convert the energy into thermal energy [3]. The thermal energy will be transferred to internal fluid thermal energy. In this way both heat and power are produced simultaneously [4]. PV cell only utilize a small fraction of the solar radiation to produce electricity. The rest of energy will be wasted and converted into heat energy to rise up PV temperature and reduce the efficiency of PV [5]. Technology of PV/T is to recover a portion of heat loss and uses it for practical applications [6]. At the same time, temperature of PV module can be reduced and can maintain electrical efficiency [7]. Hence, PV/T module offers a better way of utilizing solar energy with higher overall efficiency[8].

Flat plate $\mathrm{PV} / \mathrm{T}$ can be classified by the different of the medium for heat transfer. It can be air based, water

\footnotetext{
${ }^{\mathrm{a}}$ Corresponding author: mfirdausb@ump.edu.my
}

based or combination water/air based or refrigerant based [9].

Table 1.Efficiency with different type of coolant.[10][11][12]

\begin{tabular}{|l|c|}
\hline PV/T models & Average efficiency (\%) \\
\hline Air based & $24-47$ \\
\hline water based & $33-59$ \\
\hline refrigerant & $56-74$ \\
\hline
\end{tabular}

$\mathrm{Ji}$ et.al [13] has conducted experiment on trifunctional $\mathrm{PV} / \mathrm{T}$ system. This system can be operated in different modes which are PV/water-heating mode or PV/air heating mode. Buker et.al [14] introduced PV/T system combined with a liquid desiccant cooling system. The proposed system managed to generate $3 \mathrm{~kW}$ of heating and also $5.2 \mathrm{~kW}$ of cooling power. The effect of the distance of PV collector from supporting plate has been studied by Arpino et.al [15]. It has been concluded that an optimal distance is necessary to give better performance. Yazdanpanahi et al [16] investigated the exergy efficiency of water based $\mathrm{PV} / \mathrm{T}$ system by experimental and numerical modelling. Li Jun et.al [17] proposed a two-stage PV/T system based on solar trough concentration. The system managed to generate more thermal energy output. Yang \& Athienitis [18] conducted an experiment on two-inlet air based $\mathrm{PV} / \mathrm{T}$ system 
integrated with building. The two-inlet design has increased the heat transfer between flowing air and PV module.

The performance of $\mathrm{PV} / \mathrm{T}$ is influenced by several parameters. One of them is packing factor. Studied by Vats et.al [19] showed that optimal value of packing factor is crucial as the high value will increase the cell temperature whereas too low of the value will reduce the solar radiation absorber area. Besides that, mass flow rate is also important to gain the great efficiency of $\mathrm{PV} / \mathrm{T}$. The moving fluid can be naturally moved [20] or by force using a pump [21]. The higher the mass flow rate, the higher the convection heat transfer coefficient and will result in high thermal efficiency [22]. However, if the flow rate is too high, the efficiency might not be increased linearly as expected. On top of that, a higher operating cost is required. Hence, an optimum mass flow rate must be determined. In previous study, the mass flow rate that has been investigated range from $0.01 \mathrm{~kg} / \mathrm{s}$ to $0.3182 \mathrm{~kg} / \mathrm{s}$ [23]. $\mathrm{PV} / \mathrm{T}$ performance is also varies depending on the type of solar cell used. Amorphous silicon, single crystalline and polycrystalline are first generation of PV which made by silicon semi-conductor [24]. Second generation of PV was invented to minimize the limitation of silicon based PV. CIGS based PV thin film is one of the second generations PV. It improved flexibility and lower manufacturing cost than silicon based PV cell. Besides, thickness of CIGS thin film solar cell can be as thin as a few nanometers and very light weight[25]. Based on previous literates, the CIGS based $\mathrm{PV} / \mathrm{T}$ system is still not comprehensively studied, therefore present study will use the thin film-CIGS type of solar cell combined with flat plate solar collector.

As reported above, since mass flow rate drastically affect the performance of $\mathrm{PV} / \mathrm{T}$, it is important to understand how mass flow rate will affect the performance of CIGS based PV/T. Thus, the objective of this study is to examine the effect of mass flow rate on the power generation and thermal performance of CIGS based $\mathrm{PV} / \mathrm{T}$.

\section{Methodology}

Basic specification of PV, thermal collector and storage tank are shown in Table 2.

Table 2. Devices specification

\begin{tabular}{|l|l|}
\hline Device & Specification \\
\hline PV & Power $_{\max }=65 \mathrm{~W}$ \\
& Voltage $_{\max }=15.3 \mathrm{~V}$ \\
& Current $_{\max }=4.26 \mathrm{~A}$ \\
& ${\text { *tested at } 25^{\circ} \mathrm{C} \text { and } 1000}^{\mathrm{W} / \mathrm{m}^{2}}$ \\
\hline Thermal collector & Single glazed flat plate \\
& collector \\
& Area $=1.51 \mathrm{~m}^{2}$ \\
& Material: Full copper fin tube \\
\hline Storage Tank & Capacity: $180 \mathrm{~L}$ \\
\hline
\end{tabular}

The experiment was done on April 2015 located at the east of Malaysia with latitude $3.54^{\circ}$ and longitude $103.43^{\circ}$. Setup of experiment is shown in Figure 1. Solar radiation intensity has been measured by using pyranometer (Kipp\&Zonen CM3). Thermocouple types $\mathrm{K}$ have been used to measure the inlet and outlet temperature of solar collector and also the temperature of solar cell as well as water storage tank. Output power of $\mathrm{PV} / \mathrm{T}$ was stored in a battery through a charge controller. To prevent fully charged of battery, load was installed to consume power from battery. Cold water was pumped out from storage tank into panel to absorb thermal energy, and heated water was flowed back to the storage tank. This will increase the temperature of water in the storage tank.

A centrifugal pump with a ball valve was installed in thermal collector piping system in order to adjust water mass flow rate. Flow sensor was installed on the piping system and thermocouples were installed in water storage tank, inlet to panel and outlet from panel. Output of PV, temperature sensor and flow sensor were connected into a data logger. The uncertainty of measured parameters are listed in Table 3.

Table 3. Uncertainty for measured parameters.

\begin{tabular}{|l|c|c|}
\hline Parameter & unit & uncertainty \\
\hline ambient temperature & ${ }^{\circ} \mathrm{C}$ & \pm 0.05 \\
\hline inlet water temperature & ${ }^{\circ} \mathrm{C}$ & \pm 0.05 \\
\hline outlet water temperature & ${ }^{\circ} \mathrm{C}$ & \pm 0.05 \\
\hline solar cell temperature & ${ }^{\circ} \mathrm{C}$ & \pm 0.05 \\
\hline mass flow rate & $\mathrm{kg} / \mathrm{s}$ & \pm 0.005 \\
\hline solar iradiation intensity & $\mathrm{W} / \mathrm{m}^{2}$ & \pm 5 \\
\hline voltage & $\mathrm{V}$ & \pm 0.005 \\
\hline current & $\mathrm{A}$ & \pm 0.005 \\
\hline electrical efficiency & $\%$ & \pm 5 \\
\hline thermal efficiency & $\%$ & \pm 5 \\
\hline
\end{tabular}

Data obtained from data logger and weather monitoring systems were used for module efficiency analysis. Thermal efficiency $n_{t h}$ and electrical efficiency $n_{e l}$ can be calculated by the following equation,

$$
n_{t h}=\frac{\dot{m} C_{P}\left(T_{o u t}-T_{\text {in }}\right)}{G \cdot A}
$$

$$
n_{e l}=\frac{I V}{G \cdot A}
$$

where, $\dot{m}$ is mass flow rate, $C_{P}$ is specific heat of water, $T_{\text {out }}$ is outlet temperature of solar collector, $T_{\text {in }}$ is inlet temperature of solar collector, $\mathrm{I}$ is output current of $\mathrm{PV}$, $\mathrm{V}$ is output voltage of $\mathrm{PV}, \mathrm{G}$ is irradiance on module plane and $\mathrm{A}$ is collector area. 


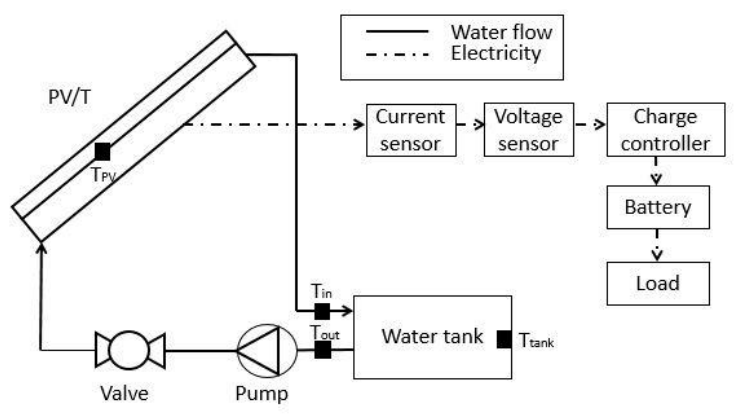

Figure 1. Schematic diagram of experiment

4 experiments were carried out as listed in Table 4.

Table 4. Experiment setup

\begin{tabular}{|c|c|c|c|}
\hline & PV & Thermal & $\begin{array}{c}\text { Mass } \\
\text { Flowrate }\end{array}$ \\
\hline 1 & No & Yes & $0.12 \mathrm{~kg} / \mathrm{s}$ \\
\hline 2 & Yes & Yes & $0.12 \mathrm{~g} / \mathrm{s}$ \\
\hline 3 & Yes & Yes & $0.09 \mathrm{~kg} / \mathrm{s}$ \\
\hline 4 & Yes & No & - \\
\hline
\end{tabular}

\section{Result and Discussion}

Efficiency of photovoltaic cell and thermal collector is strongly related with ambient temperature and also irradiance value. Hence, data collected by weather monitoring system is required. Figure 2 is a double y-axis graph to show the irradiance and ambient temperature against time for 4 experiments.

As shown in Figure 2, irradiance value normally can reach over $1000 \mathrm{~W} / \mathrm{m}^{2}$ during noon time. Whereas the average irradiance value for $0.12 \mathrm{~kg} / \mathrm{s}$ mass flow rate thermal collector was $665.13 \mathrm{~W} / \mathrm{m}^{2}, 0.12 \mathrm{~kg} / \mathrm{s}$ mass flow rate of $\mathrm{PV} / \mathrm{T}$ was $602.91 \mathrm{~W} / \mathrm{m}^{2}, 0.09 \mathrm{~kg} / \mathrm{s}$ mass flow rate for $\mathrm{PV} / \mathrm{T}$ was $629.92 \mathrm{~W} / \mathrm{m}^{2}$ and $\mathrm{PV}$ was $689.04 \mathrm{~W} / \mathrm{m}^{2}$. $0.12 \mathrm{~kg} / \mathrm{s}$ mass flow rate of $\mathrm{PV} / \mathrm{T}$ having the least irradiation value compare to others. This is due to light rain in the morning time. The average day time temperature for $0.12 \mathrm{~kg} / \mathrm{s}$ thermal collector was $31.53{ }^{\circ} \mathrm{C}$, $0.12 \mathrm{~kg} / \mathrm{s}$ mass flow rate for PV/T was $33.1^{\circ} \mathrm{C}, 0.09 \mathrm{~kg} / \mathrm{s}$ mass flow rate of $\mathrm{PV} / \mathrm{T}$ was $32.9{ }^{\circ} \mathrm{C}$ and $\mathrm{PV}$ was 33.22 ${ }^{\circ} \mathrm{C}$. Maximum ambient temperature can be reached during noon time is around $35^{\circ} \mathrm{C}$. Figure 2 also shows the relationship between irradiance and ambient temperature. When the value of irradiance is low, ambient temperature will drop.

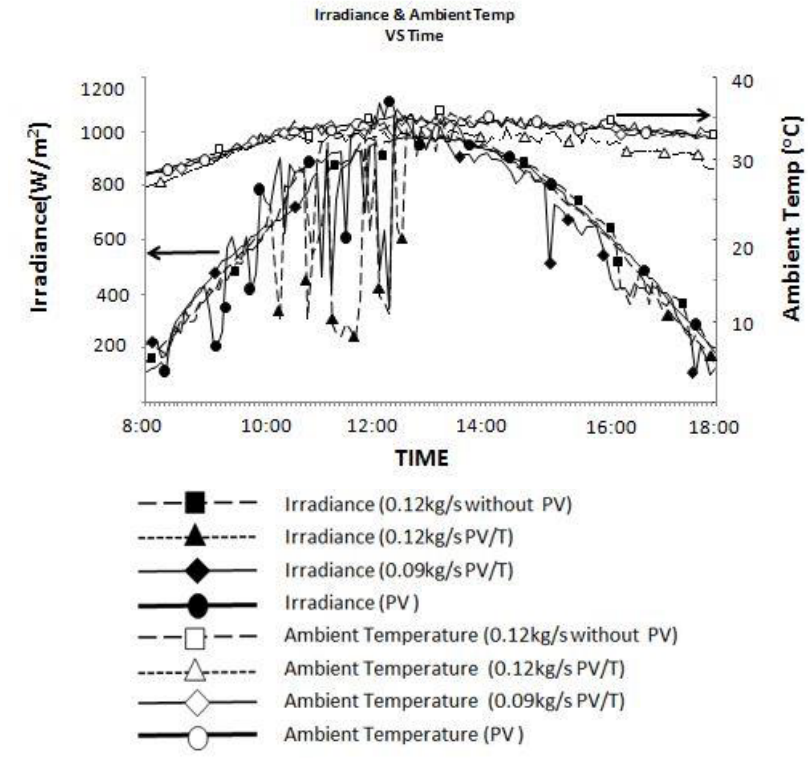

Figure 2. Graph Irradiance and Ambient Temperature VS Time

As shown in Figure 3, if PV cell is not combined with thermal collector, the temperature of PV can reach as high as $106{ }^{\circ} \mathrm{C}$. If it is combined with thermal collector, temperature of PV is relatively low with higher mass flow rate. Maximum PV temperature for $0.12 \mathrm{~kg} / \mathrm{s}$ mass flow rate is around $70{ }^{\circ} \mathrm{C}$, and $80{ }^{\circ} \mathrm{C}$ for $0.09 \mathrm{~kg} / \mathrm{s}$ mass flow rate. Solar thermal collector play an important role in decreasing the temperature of PV.

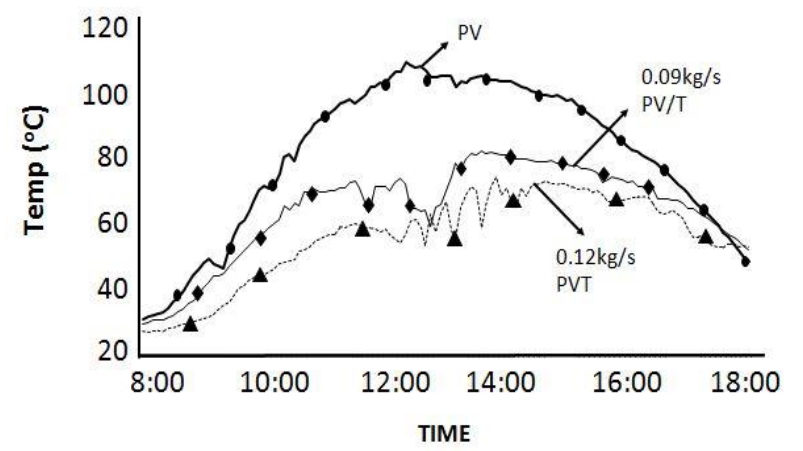

Figure 3. Graph of PV Temperature VS Time

Figure 4 shows the efficiency of PV throughout the day. The average efficiency for flow rate $0.12 \mathrm{~kg} / \mathrm{s}, 0.09$ $\mathrm{kg} / \mathrm{s}$ and PV without thermal collector is $2.92 \%, 2.68 \%$ and $1.86 \%$ respectively. Based on Figure 3 and Figure 4, the efficiency of PV is strongly depending on PV temperature. The efficiency gained by the CIGS was low due to several factors. The rated power from the manufacturer is already low which $65 \mathrm{~W}$ with area, 1.51 $\mathrm{m} 2$ is. On the other hand, the packing factor of the CIGS need to be considered as it may not be operated at the optimal packing factor. Moreover, aluminium sheet under the solar cell may affect the temperature of the PV due to high thermal conductivity. 


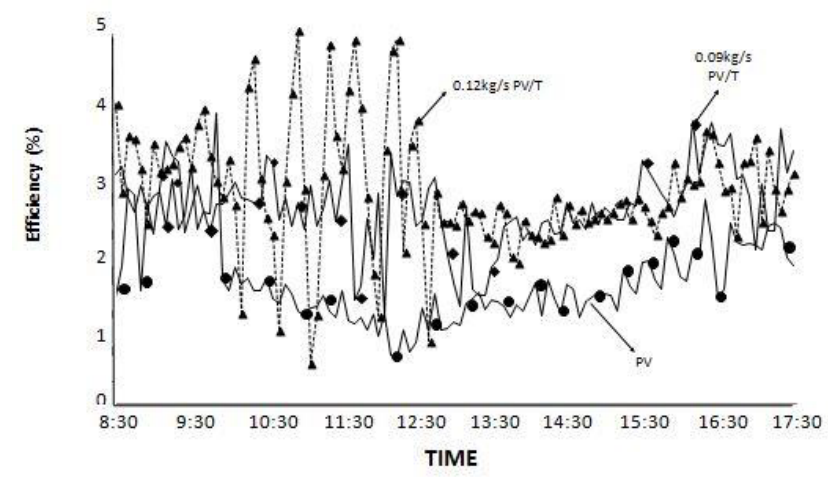

Figure 4. Efficiency of PV VS Time

As shown in Figure 5, maximum water temperature in tank is around $46{ }^{\circ} \mathrm{C}$. Water can reach $46{ }^{\circ} \mathrm{C}$ at $3 \mathrm{pm}$ for $0.12 \mathrm{~kg} / \mathrm{s}$ mass flow rate of thermal collector, but water for both $\mathrm{PV} / \mathrm{T}$ reaches $46{ }^{\circ} \mathrm{C}$ around $4 \mathrm{pm}$. This means that, thermal collector had the highest thermal efficiency among other experiments. Solar thermal collector will be beneficial if heat is prior for load demand. However for power prior load demand, combined solar thermal with PV is necessary.

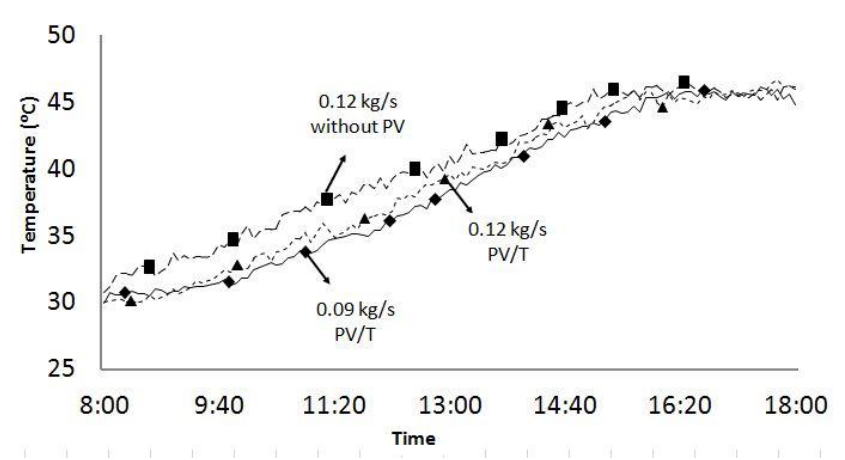

Figure 5. Water Temperature in Storage Tank VS Time

Table 5. Thermal, PV and total efficiency for 4 experiments

\begin{tabular}{|l|c|c|c|c|}
\hline & $\begin{array}{c}0.12 \mathrm{~kg} / \mathrm{s} \\
\text { Thermal } \\
\text { Collector }\end{array}$ & $\begin{array}{c}0.12 \mathrm{~kg} / \mathrm{s} \\
\text { PVT }\end{array}$ & $\begin{array}{c}0.09 \mathrm{~kg} / \mathrm{s} \\
\text { PVT }\end{array}$ & PV \\
\hline $\begin{array}{l}\text { Thermal } \\
\text { Efficiency (\%) }\end{array}$ & 77.16 & 56.08 & 54.13 & - \\
\hline $\begin{array}{l}\text { PV Efficiency } \\
(\%)\end{array}$ & - & 2.92 & 2.68 & 1.86 \\
\hline $\begin{array}{l}\text { Total Efficiency } \\
(\%)\end{array}$ & - & 59 & 56.81 & - \\
\hline
\end{tabular}

Electrical efficiency and thermal efficiency of all experiments is concluded in Table 5. PV/T with mass flow $0.12 \mathrm{~kg} / \mathrm{s}$ gained the highest total efficiency with 59 $\%$, following by PV/T with mass flow rate $0.09 \mathrm{~kg} / \mathrm{s}$ with $56.81 \%$ total efficiency. In term of electricity consideration, $\mathrm{PV} / \mathrm{T}$ with mass flow rate $0.12 \mathrm{~kg} / \mathrm{s}$ is more beneficial as the electrical efficiency is $2.92 \%$. Whereas, when the primary load is heat, solar thermal collector is more beneficial as the thermal efficiency gained is the highest which is $77.16 \%$.

\section{Conclusion}

In conclusion, higher efficiency of PV can be achieved at the higher mass flow rate. When combining $\mathrm{PV}$ with thermal collector with the flow rate of $0.12 \mathrm{~kg} / \mathrm{s}$, PV efficiency was $2.92 \%$. PV efficiency for $0.09 \mathrm{~kg} / \mathrm{s}$ of $\mathrm{PV} / \mathrm{T}$ was $1.95 \%$ lower compared to $0.12 \mathrm{~kg} / \mathrm{s}$ of $\mathrm{PV} / \mathrm{T}$. However, efficiency of PV is low, if the PV is standalone without using any cooling mechanism. Efficiency for standalone PV can be as low as $1.86 \%$. Efficiency for thermal collector will drop up to $20 \%$ after PV module is attached on it. Efficiency of PV is able to improve after combined with thermal collector. However, in the present study the variable mass flow rate is only limited to 2 value, which is insufficient to determine the optimal mass flow rate. The efficiency might increase in higher mass flow rate or at some point it will not increasing proportionally. Thus, further study that includes various number of mass flow rate is necessary.

\section{References}

[1] R. Daghigh, M. H. Ruslan, and K. Sopian, "Advances in liquid based photovoltaic/thermal (PV/T) collectors," Renew. Sustain. Energy Rev., vol. 15, no. 8, pp. 4156-4170, Oct. 2011. F. Hussain, M. Y. H. Othman, K. Sopian, B. Yatim, H. Ruslan, and H. Othman, "Design development and performance evaluation of photovoltaic/thermal (PV/T) air base solar collector," Renew. Sustain. Energy Rev., vol. 25, pp. 431-441, 2013.

F. Sarhaddi, S. Farahat, H. Ajam, a. Behzadmehr, and M. Mahdavi Adeli, "An improved thermal and electrical model for a solar photovoltaic thermal (PV/T) air collector," Appl. Energy, vol. 87, no. 7, pp. 2328-2339, Jul. 2010.

[4] V. V. Tyagi, S. C. Kaushik, and S. K. Tyagi, "Advancement in solar photovoltaic/thermal (PV/T) hybrid collector technology," Renew. Sustain. Energy Rev., vol. 16, no. 3, pp. 13831398, Apr. 2012.

[5] Y. Gao, P. Ying, J. Cui, S. Chen, and Y. Li, "Thermoelectric Properties of $\mathrm{Cu}$ and $\mathrm{Sb} \mathrm{Co}-$ Doped Ga-Te Based Semiconductor with Wide Band Gap," Procedia Eng., vol. 27, pp. 156-162, 2012.

[6] P. G. Charalambous, G. G. Maidment, S. a. Kalogirou, and K. Yiakoumetti, "Photovoltaic thermal (PV/T) collectors: A review," Appl. Therm. Eng., vol. 27, no. 2-3, pp. 275-286, Feb. 2007.

[7] H. A. Zondag, D. W. De Vries, W. G. J. Van Helden, and R. J. C. Van Zolingen, "T he yield of different combined PV-thermal collector designs," vol. 74, pp. 253-269, 2003.

[8] T. Fujisawa and T. Tani, "Annual exergy evaluation on photovoltaic-thermal hybrid collector," Sol. Energy Mater. Sol. Cells, vol. 47, no. 1-4, pp. 135-148, 1997. 
[9] A. Ibrahim, M. Y. Othman, M. H. Ruslan, S. Mat, and K. Sopian, "Recent advances in flat plate photovoltaic/thermal (PV/T) solar collectors," Renew. Sustain. Energy Rev., vol. 15, no. 1, pp. 352-365, Jan. 2011.

[10] S. C. Solanki, S. Dubey, and A. Tiwari, "Indoor simulation and testing of photovoltaic thermal (PV/T) air collectors," Appl. Energy, vol. 86, no. 11, pp. 2421-2428, 2009.

[11] T. H. Lin, W. C. Hung, and F. S. Sun, "PERFORMANCE EVALUATION OF SOLAR PHOTOVOLTAIC / THERMAL SYSTEMS," vol. 70, no. 5, pp. 443-448, 2001.

[12] J. Ji, G. Pei, T. T. Chow, K. Liu, H. He, J. Lu, and C. Han, "Experimental study of photovoltaic solar assisted heat pump system," Sol. Energy, vol. 82, no. 1, pp. 43-52, 2008.

[13] J. Ji, C. Guo, W. Sun, W. He, Y. Wang, and G. Li, "Experimental investigation of tri-functional photovoltaic/thermal solar collector," Energy Convers. Manag., vol. 88, pp. 650-656, 2014.

[14] M. S. Buker, B. Mempouo, and S. B. Riffat, "Experimental investigation of a building integrated photovoltaic/thermal roof collector combined with a liquid desiccant enhanced indirect evaporative cooling system," Energy Convers. Manag., vol. 101, pp. 239-254, 2015.

[15] F. Arpino, G. Cortellessa, and a. Frattolillo, "Experimental and numerical assessment of photovoltaic collectors performance dependence on frame size and installation technique," Sol. Energy, vol. 118, pp. 7-19, 2015.

[16] J. Yazdanpanahi, F. Sarhaddi, and M. Mahdavi Adeli, "Experimental investigation of exergy efficiency of a solar photovoltaic thermal (PVT) water collector based on exergy losses," Sol. Energy, vol. 118, pp. 197-208, 2015.

[17] L. Tan, X. Ji, M. Li, C. Leng, X. Luo, and H. Li, "The experimental study of a two-stage photovoltaic thermal system based on solar trough concentration," Energy Convers. Manag., vol. 86, pp. 410-417, 2014.
[18] T. Yang and A. K. Athienitis, "Experimental investigation of a two-inlet air-based building integrated photovoltaic/thermal (BIPV/T) system," Appl. Energy, vol. 159, pp. 70-79, 2015.

[19] K. Vats, V. Tomar, and G. N. Tiwari, "Effect of packing factor on the performance of a building integrated semitransparent photovoltaic thermal (BISPVT) system with air duct," Energy Build., vol. 53, pp. 159-165, Oct. 2012.

[20] T. T. Chow, W. He, and J. Ji, "Hybrid photovoltaic-thermosyphon water heating system for residential application," Sol. Energy, vol. 80, no. 3, pp. 298-306, Mar. 2006.

[21] A. Tiwari and M. S. Sodha, "Performance evaluation of hybrid PV/thermal water/air heating system: A parametric study," Renew. Energy, vol. 31, no. 15, pp. 2460-2474, Dec. 2006.

[22] T. T. Chow, "A review on photovoltaic/thermal hybrid solar technology," Appl. Energy, vol. 87, no. 2, pp. 365-379, Feb. 2010.

[23] K. Moradi, M. Ali Ebadian, and C.-X. Lin, "A review of PV/T technologies: Effects of control parameters," Int. J. Heat Mass Transf., vol. 64, pp. 483-500, Sep. 2013.

[24] E. Franklin, V. Everett, A. Blakers, and K. Weber, "Sliver solar cells: High-efficiency, low-cost PV technology," Adv. Optoelectron., vol. 2007, 2007.

[25] X. Zhang, X. Zhao, S. Smith, J. Xu, and X. Yu, "Review of R\&D progress and practical application of the solar photovoltaic/thermal (PV/T) technologies," Renew. Sustain. Energy Rev., vol. 16, no. 1, pp. 599-617, Jan. 2012. 